\title{
Improved Diagnoses and Quantification of Fusarium virguliforme, Causal Agent of Soybean Sudden Death Syndrome
}

\author{
Jie Wang, Janette L. Jacobs, Jan M. Byrne, and Martin I. Chilvers
}

Department of Plant, Soil and Microbial Sciences, Michigan State University, East Lansing 48824.

Accepted for publication 29 September 2014.

\begin{abstract}
Wang, J., Jacobs, J. L., Byrne, J. M., and Chilvers, M. I. 2015. Improved diagnoses and quantification of Fusarium virguliforme, causal agent of soybean sudden death syndrome. Phytopathology 105:378-387.

Fusarium virguliforme (syn. F. solani f. sp. glycines) is the primary causal pathogen responsible for soybean sudden death syndrome (SDS) in North America. Diagnosis of SDS is difficult because symptoms can be inconsistent or similar to several soybean diseases and disorders. Additionally, quantification and identification of $F$. virguliforme by traditional dilution plating of soil or ground plant tissue is problematic due to the slow growth rate and plastic morphology of $F$. virguliforme. Although several real-time quantitative polymerase chain reaction (qPCR)-based assays have been developed for $F$. virguliforme, the performance of those assays does not allow for accurate quantification of $F$. virguliforme due to the reclassification of the $F$. solani species complex. In this study, we

intergenic spacer (IGS) region of $F$. virguliforme. Specificity of the assay was demonstrated by challenging it with genomic DNA of closely related Fusarium spp. and commonly encountered soilborne fungal pathogens. The detection limit of this assay was determined to be $100 \mathrm{fg}$ of pure $F$. virguliforme genomic DNA or 100 macroconidia in $0.5 \mathrm{~g}$ of soil. An exogenous control was multiplexed with the assay to evaluate for PCR inhibition. Target locus copy number variation had minimal impact, with a range of rDNA copy number from 138 to 233 copies per haploid genome, resulting in a minor variation of up to 0.76 cycle threshold values between strains. The qPCR assay is transferable across platforms, as validated on the primary real-time PCR platform used in the Northcentral region of the National Plant Diagnostic Network. A conventional PCR assay for $F$. virguliforme detection was also developed and validated for use in situations where qPCR is not possible.
\end{abstract} developed a TaqMan qPCR assay based on the ribosomal DNA (rDNA)
Additional keyword: diagnostic.
Within the United States, soybean (Glycine max (L.) Merr.) is the second most widely grown crop, with more than 3 billion bushels produced per annum (United States Department of Agriculture, National Agricultural Statistics Service, 2013). Numerous plant diseases threaten soybean production in the United States, including soybean sudden death syndrome (SDS) (43). In the past decade, SDS has ranked within the top five most yield-damaging soybean diseases in the United States, with estimated yield losses of 70 million bushels in 2010 (44). In North America, the predominant causal agent of soybean SDS is the soilborne fungal pathogen Fusarium virguliforme (3). F. virguliforme has been reported to colonize a wide range of host plant species (21), and can survive in soil or debris by producing conidia or chlamydospores (38). Diagnosis of SDS in the field can be difficult because several other diseases can produce similar symptoms, such as brown stem rot (BSR) caused by Phialophora gregata $(=$ Cadophora gregata $)$ or red crown rot caused by Cylindrocladium parasiticum (38).

Studies suggest that early infection of soybean plants by $F$. virguliforme is essential for foliar SDS symptom development (30), and infection by $F$. virguliforme was detected as early as the seedling stage (13). As a soilborne pathogen, F. virguliforme only colonizes the root and the lower stem of soybean plants (39); phytotoxins produced by the fungus are translocated through the xylem to the foliage, causing SDS foliar symptoms (7). Accurate

Corresponding author: M. I. Chilvers; E-mail address: chilvers@msu.edu

* The $\boldsymbol{e}$-Xtra logo stands for "electronic extra" and indicates that the online version contains five supplemental figures.

http://dx.doi.org/10.1094/PHYTO-06-14-0177-R

(c) 2015 The American Phytopathological Society detection and quantification of $F$. virguliforme in root and soil samples are essential to study the epidemiology of $F$. virguliforme. Both culture-based and molecular polymerase chain reaction (PCR)-based methods have been developed for the detection of $F$. virguliforme. Culture-based methods utilize dilution plating or isolation from infected tissue on semiselective media $(10,26$, 37,39). However, these culture-based methods are time consuming and can be difficult to implement given the slow growth rate and plastic morphology of $F$. virguliforme $(3,10)$. These limitations of sensitivity and specificity led to the development of DNAbased molecular detection tools. Multiple conventional PCR assays have been developed for the detection of $F$. virguliforme but they are not specific due to the revised taxonomy of the $F$. solani species complex $(1,23,32)$. Therefore, no specific conventional PCR assay is currently available for diagnosis of $F$. virguliforme.

Quantitative real-time PCR (qPCR) has been extensively applied in quantification and diagnosis of numerous plant pathogens. Compared with conventional PCR assay, qPCR assays can be more sensitive and specific and can detect multiple pathogens by multiplexing assays $(35,40)$. Gao et al. (14) and $\mathrm{Li}$ et al. (24) reported two qPCR assays for quantification of $F$. virguliforme from plant samples using TaqMan probe assays designed against the mitochondrial small-subunit (SSU) ribosomal DNA (rDNA) sequence. Due to the reclassification of the F. solani species complex, the mitochondrial DNA (mtDNA) region used for design of these two assays was too conserved to differentiate $F$. virguliforme from the dry bean root rot pathogens $F$. cuneirostrum and F. phaseoli and other SDS causal agents such as F. tucumaniae, $F$. crassistipitatum, and $F$. brasiliense, which predominate in South America $(5,33)$. Therefore, it is clear that qPCR assays for F. virguliforme need to be improved. O'Donnell et al. (33) and Aoki et al. (5) demonstrated that the intergenic spacer (IGS) 
region of the rDNA is one of the genetic loci that can resolve $F$. virguliforme from the other closely related Fusarium spp. in their multilocus genotyping studies of clade $2 F$. solani species complex. The rDNA IGS region is a multicopy genetic locus in the eukaryotic genome (25); therefore, the sensitivity of the assay based on the IGS rDNA region is greater than a single-copy gene assay, and has been used for detection and quantification of numerous plant pathogens $(6,9,15)$. Although the rDNA IGS region seems an ideal region for qPCR assay design, large rDNA copy number variations were reported in many fungal organisms $(6,18)$, and accuracy of the quantification may be affected in plants infected by fungal strains with varied rDNA copy numbers. In addition, PCR inhibitors in DNA samples can cause falsenegative results or low PCR amplification efficiencies. Strategies to deal with PCR inhibitors include dilution of DNA samples (27), additional DNA purification steps, or the use of PCR additives such as polyvinylpolypyrrolidone $(19,28)$ and bovine serum albumin (BSA) (16). Despite attempts to reduce or remove PCR inhibitors, an internal or exogenous control is needed to monitor each reaction for PCR inhibition.

Soybean SDS is becoming one of the most devastating diseases threatening soybean production across most of the soybean production zones in the United States, and its range continues to expand. Despite this, an accurate, robust, and sensitive diagnostic and quantitative assay is not available. Therefore, development of such an assay will facilitate the diagnosis of SDS, and can be used to study the epidemiology of $F$. virguliforme, which will improve our understanding and management of this pathogen. The objectives of this study were to (i) develop a qPCR assay with the inclusion of an internal control for the sensitive and specific detection and quantification of $F$. virguliforme, (ii) determine the transferability of the qPCR assay between platforms, (iii) develop a complimentary conventional PCR assay for use in situations where qPCR is not possible, and (iv) thoroughly validate the qPCR and PCR assays with plant and soil samples.

\section{MATERIALS AND METHODS}

Fungal isolates and DNA extraction. Thirty-six isolates of Fusarium spp. and other genera commonly found associated with soybean were used in this study (Table 1). Cultures of Fusarium spp. were grown on potato dextrose agar (PDA) media (Acumedia, Burton, $\mathrm{MI}$ ) at room temperature for 14 days, and agar plugs with conidia were collected and stored at $-80^{\circ} \mathrm{C}$ in $20 \%$ glycerol. To obtain mycelia for DNA extraction, seven to eight $4-\mathrm{mm}^{3}$ pieces of colonized PDA media were transferred to $50 \mathrm{ml}$ of potato dextrose broth (PDB) (Acumedia) in 250-ml Erlenmeyer flasks and shaken at room temperature on an orbital rotary shaker at

TABLE 1. Specificity test panel for quantitative polymerase chain reaction (qPCR) assay validation ${ }^{\mathrm{a}}$

\begin{tabular}{|c|c|c|c|c|}
\hline Species ${ }^{b}$ & $\mathrm{Ct}^{\mathrm{c}}$ & $\mathrm{NRRL}^{\mathrm{d}}$ & Host $^{\mathrm{e}}$ & Geographic origin \\
\hline Fusarium acuminatum ${ }^{\mathrm{f}}$ & 35.75 & - & Solanum tuberosum & Michigan \\
\hline F. avenaceum ${ }^{\mathrm{f}}$ & 35.07 & - & S. tuberosum & Michigan \\
\hline F. brasiliense & 32.06 & 22678 & Glycine $\max$ & California \\
\hline F. brasiliense & 36.21 & 22743 & G. $\max$ & Brasilia, Distrito Federal, Brazil \\
\hline F. cerealis $^{\mathrm{f}}$ & 34.11 & - & S. tuberosum & Michigan \\
\hline F. crassistipitatum & 36.04 & 31949 & G. $\max$ & Cristalina, Goias, Brazil \\
\hline F. cuneirostrum & 33.05 & 31157 & Phaseolus vulgaris & Presque Isle, Michigan \\
\hline F. equiseti $\mathrm{f}^{\mathrm{f}}$ & 34.29 & - & S. tuberosum & Michigan \\
\hline Fusarium sp.* & 32.6 & 22574 & Coffea arabica & Guatemala \\
\hline Fusarium sp.* & 35.54 & 22412 & Bark & French Guiana \\
\hline F. graminearum $^{\mathrm{f}}$ & 34.91 & - & S. tuberosum & Michigan \\
\hline Fusarium sp.* & 31.35 & 22387 & Bark & French Guian \\
\hline F. oxysporum ${ }^{\mathrm{f}}$ & 36.07 & - & S. tuberosum & Michigan \\
\hline F. phaseoli & 37.18 & 22276 & P. vulgaris & United States \\
\hline F. phaseoli & 36.47 & 31156 & P. vulgaris & Michigan \\
\hline F. sambucinum ${ }^{\mathrm{f}}$ & 37.36 & - & S. tuberosum & Michigan \\
\hline F. solani & 37.19 & 22395 & Bark & Venezuela \\
\hline F. solani ${ }^{\mathrm{f}}$ & 35.21 & - & S. tuberosum & Michigan \\
\hline F. torulosum ${ }^{\mathrm{f}}$ & 34.58 & - & S. tuberosum & Michigan \\
\hline F. tricinctum $^{\mathrm{f}}$ & 35.31 & - & S. tuberosum & Michigan \\
\hline F. tucumaniae & 38.57 & 31096 & G. $\max$ & San Agustin, Tucuman, Argentina \\
\hline F. tucumaniae & 37.15 & 31773 & G. $\max$ & Brazil, PR, Ponta Grossa \\
\hline F. virguliforme & 21.78 & 22823 & G. $\max$ & Indiana \\
\hline F. virguliforme & 20.88 & 31041 & G. $\max$ & Illinois \\
\hline F. virguliforme & 21.08 & 34551 & G. $\max$ & San Pedrom, Buenos Aures, Argentina \\
\hline F. virguliforme & 20.53 & 22292 & G. $\max$ & Illinois \\
\hline F. virguliforme & 19.36 & - & G. $\max$ & Counties across Michigan \\
\hline Phialophora gregata $(\mathrm{B})$ & 34.84 & - & G. $\max$ & - \\
\hline P. $\operatorname{gregata}(\mathrm{A})$ & 33.82 & - & G. $\max$ & - \\
\hline Phytophthora sansomeana & 34.9 & - & G. $\max$ & - \\
\hline P. sojae & 35.98 & - & G. $\max$ & - \\
\hline Pythium svlvaticum & 34.21 & - & G. $\max$ & - \\
\hline P. ultimum & 34.93 & - & G. $\max$ & - \\
\hline Rhizoctonia solani AG-2-2IIIB & 34.93 & - & - & - \\
\hline R. solani $\mathrm{AG}-4$ & 34.99 & - & - & - \\
\hline Sclerotinia sclerotiorum & 35.36 & - & G. $\max$ & - \\
\hline
\end{tabular}

a This table includes the Fusarium spp. that are closely related to the Fusarium spp. that cause sudden death syndrome and other commonly encountered soil fungal species. Cycle threshold $(\mathrm{Ct})$ values listed in the table indicate the specificity performance of the Fusarium virguliforme quantitative polymerase chain reaction assay when $100 \mathrm{pg}$ of genomic DNA were added to the reaction.

b Asterisk (*) indicates unnamed Fusarium spp. nested within clade two of the F. solani species complex (34).

${ }^{c} \mathrm{Ct}$ values were determined by setting the threshold line at 0.1 .

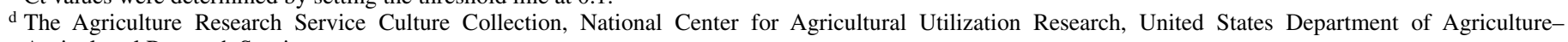
Agricultural Research Service.

e Host plants for the microorganisms.

f Species isolates obtained from the study published by Gachango et al. (12). 
$120 \mathrm{rpm}$ for 3 to 4 days. Mycelia were collected by vacuum filtration on Miracloth (Calbiochem, Darmstadt, Germany) with a Buchner funnel, frozen, and lyophilized in sterile 2-ml microcentrifuge tubes overnight. Lyophilized mycelia $(20 \mathrm{mg})$ were disrupted in 2-ml screw-cap tubes with one 6-mm ceramic bead and five 2-mm glass beads in a FastPrep FP120 Bio101 Savant machine (Qbiogene, Carlsbad, CA) at the speed setting 6 for $40 \mathrm{~s}$. Mycelia were used for DNA extraction using the DNeasy Plant Mini kit (Qiagen, Germantown, MD). DNA concentration was determined with a Quant-iT double-stranded DNA (dsDNA) highsensitivity assay kit (Invitrogen, Carlsbad, CA) on a 96-well SAFIRE microplate reader (TECAN, Männedorf, Switzerland).

Real-time PCR primer and probe design for $F$. virguliforme. The multicopy-number IGS region of the rDNA was chosen to design primers and probes. IGS rDNA sequences of Fusarium spp. (Table 1) were obtained from the National Center for Biotechnology Information GenBank database (FJ919498, FJ919499, FJ919507, FJ919510, FJ919511, FJ919512, FJ919515, and FJ919521). Eight IGS rDNA sequences from the soybean SDS and bean root rot (BRR) clade of Fusarium spp. (i.e., F. virguliforme, $F$. tucumaniae, $F$. cuneirostrum, $F$. crassistipitatum, $F$. brasiliense, and $F$. phaseoli) were chosen for multiple sequence alignment to find the unique polymorphic regions of $F$. virguliforme using the multiple sequence comparison by log-expectation (MUSCLE) method (11). In addition, the sequence self-repeat structure was viewed using the 'dottup' package in EMBOSS (36) to avoid cross amplification within the IGS rDNA region. Primers were designed to amplify PCR product sizes of 50 to $150 \mathrm{bp}$. Polymorphic nucleotides unique to $F$. virguliforme were designed at the $3^{\prime}$ end of the primers and the middle of probes. Melting temperature $(\mathrm{Tm})$ for the primer oligos was predicted using the primer probe test tool in Primer Express 3.0 (Applied Biosystems, Carlsbad, CA). The secondary structure of the target amplicon was predicted with the 'mfold' software package (45) at the temperature of PCR annealing step and with the final $\left[\mathrm{Mg}^{2+}\right]=2 \mathrm{mM}$ and $\left[\mathrm{Na}^{+}\right]=50 \mathrm{mM}$. The free energy $(\Delta \mathrm{G})$ was used to evaluate the stability of the amplicon secondary structure, and the PCR product with a higher $\Delta \mathrm{G}$ was selected as test candidate for further evaluation. For the probe design, the following rules were applied: probe $\mathrm{Tm} 10^{\circ} \mathrm{C}$ higher than primer Tm; 15 to 30 nucleotides in length; avoid $\mathrm{G}$ on the $5^{\prime}$ end; and place the mismatching nucleotides in the middle of the probe instead of both ends. The $5^{\prime}$ end of the TaqMan probe (Life Technologies) for $F$. virguliforme was labeled with 6-fluorescein (6-FAM), and the $3^{\prime}$ end was modified with a minor groove binder and nonfluorescent quencher. Other PrimeTime dual-labeled probes (IDT, Coralville, Iowa) were labeled with 5' 6-FAM, internal ZEN quencher, and 3' Iowa Black FQ quencher. The exogenous control HHIC assay primers and probe were ordered from IDT as describe by Haudenshield and Hartman (16).

qPCR amplification parameters. Real-time qPCR amplifications were performed on the ABI StepOnePlus thermocycler v2.3 (Applied Biosystems). Real-time qPCR was performed in a $20-\mu$ total volume with at least two technical repeats. The qPCR mix consisted of $10 \mu$ of TaqMan Universal real-time PCR master mix (2x) (Applied Biosystems), $2 \mu \mathrm{l}$ of DNA template, $0.5 \mu \mathrm{l}$ of FvPrb-3 $(10 \mu \mathrm{M}), 0.5 \mu \mathrm{l}$ of F6-3 and R6 primers $(20 \mu \mathrm{M}), 0.6 \mu \mathrm{l}$ of HHIC-F $(20 \mu \mathrm{M})$ primer, $0.2 \mu \mathrm{l}$ of HHIC-R $(20 \mu \mathrm{M}), 0.4 \mu \mathrm{l}$ of HHIC-prb $(10 \mu \mathrm{M}), 0.5 \mu \mathrm{l}$ of linearized HHIC DNA plasmid $(10 \mathrm{fg} / \mu \mathrm{l})(16), 0.4 \mu \mathrm{l}$ of BSA at $10 \mathrm{mg} / \mathrm{ml}$, and $4.4 \mu \mathrm{l}$ of distilled water (Gibco, Grand Island, NY). qPCR conditions were initialized with 1 cycle of incubation at $50^{\circ} \mathrm{C}$ for 2 min to activate uracil-N-glycosylase, 1 cycle at $95^{\circ} \mathrm{C}$ for $10 \mathrm{~min}$, and 40 cycles at $95^{\circ} \mathrm{C}$ for $15 \mathrm{~s}$ and $60^{\circ} \mathrm{C}$ for $1 \mathrm{~min}$, with fluorescent data collection in the annealing and extension step.

Real-time PCR specificity and sensitivity tests. For the specificity tests, $100 \mathrm{pg}$ of genomic DNA template of target and nontarget species (Table 1) were tested against the designed assays.
Only the assays with specificity to $F$. virguliforme were evaluated in the validation step. To determine the PCR efficiency and sensitivity, a 10 -fold $F$. virguliforme genomic DNA serial dilution from $10 \mathrm{ng}$ to $1 \mathrm{fg}$ was tested with the specific qPCR assay. PCR efficiency was calculated with the formula: efficiency $=10^{(-1 / \text { slope })}-$ 1 (slope was calculated from the linear regression between DNA $\log _{10}$ [template DNA concentrations] and cycle threshold [Ct] values). $F$. virguliforme genomic DNA serial dilutions were diluted with salmon sperm DNA (Invitrogen) at $1 \mathrm{ng} / \mu \mathrm{l}$ to increase the stability of the low concentration DNA and protect against degradation or affinity to the plastic tubes.

Conventional PCR amplification parameters. Multiple primer sets were designed for the conventional PCR assay. To ensure ease of PCR amplification and product visualization in an agarose gel, the amplicon size was designed to be between 300 and 400 bp. Conventional PCR assays were performed with an ABI 2720 Thermal Cycler (Applied Biosystems). Conventional PCR was performed in a total volume of $25 \mu \mathrm{l}$, which included $2.5 \mu \mathrm{l}$ of 10x DreamTaq DNA buffer (Thermo Fisher Scientific, Waltham, MA), $0.2 \mu \mathrm{l}$ of $25 \mu \mathrm{M}$ dNTPs (Promega Corp., Madison, WI), $1 \mu \mathrm{l}$ of $10 \mu \mathrm{M}$ primers (Sigma-Aldrich, St. Louis), $0.2 \mu \mathrm{l}(5 \mathrm{U} / \mu \mathrm{l})$ of DreamTaq DNA polymerase (Thermo Fisher Scientific), $0.5 \mu \mathrm{l}$ of BSA at $10 \mathrm{mg} / \mathrm{ml}, 2 \mu \mathrm{l}$ of DNA template, and distilled water to a total volume of $25 \mu \mathrm{l}$. PCR cycling conditions were set at 1 cycle at $94^{\circ} \mathrm{C}$ for $3 \mathrm{~min}$; followed by 35 cycles of $30 \mathrm{~s}$ at $94^{\circ} \mathrm{C}, 30 \mathrm{~s}$ at $65^{\circ} \mathrm{C}$, and $30 \mathrm{~s}$ at $72^{\circ} \mathrm{C}$; and a final extension for $5 \mathrm{~min}$ at $72^{\circ} \mathrm{C}$. PCR products were separated and visualized on a $1.5 \%$ agarose gel at $85 \mathrm{~V}$ for $45 \mathrm{~min}$ and stained with ethidium bromide at $1 \mu \mathrm{g} / \mathrm{ml}$. Genomic DNA of $F$. virguliforme was serially diluted 1:10 from $10 \mathrm{ng}$ to $1 \mathrm{fg}$ to test the sensitivity of the conventional PCR assay. Also, $100 \mathrm{pg}$ of genomic DNA from the specificity check panel (Table 1) was tested against the conventional PCR assay.

DNA extraction from soil. To determine the applicability of the qPCR assay to soil samples, DNA was extracted from artificially inoculated and naturally infested soil samples. In artificially inoculated soil samples, $0.5 \mathrm{~g}$ of soil was inoculated with $100 \mu \mathrm{l}$ of 1:10 serially diluted $F$. virguliforme spore suspensions in sterile deionized water, with concentrations ranging from $10^{8}$ to 100 spores $/ \mathrm{ml}$. A half-gram of moist Riddles-Hillsdale sandy loam soil was placed into a 2-ml lysing matrix $\mathrm{E}$ tube with the FastDNA SPIN kit for soil (MP Bio, Solon, OH). After adding $978 \mu \mathrm{l}$ of sodium phosphate buffer and $122 \mu \mathrm{l}$ of MT buffer, the tubes were placed in a FastPrep FP120 instrument (MP Bio) and homogenized twice at speed 6 for 40 s. Subsequent steps were performed according to the manufacturer's recommendations; DNA was eluted with a final volume of $100 \mu$ l of DNase/pyrogenfree water (DES) (MP Biomedicals).

DNA extraction from soybean roots. Soybean roots with SDS-like foliar or root rot symptoms were collected from commercial fields and from samples submitted to the Michigan State University Diagnostic Services Laboratory. Roots were washed with tap water, rinsed with deionized water, and patted dry with a paper towel. Lateral or tap root tissues with obvious discoloration or lesions were preferred for DNA extraction; two technical replicates were made for each processed sample. Root tissue (100 mg) was added to a 2-ml lysing tube with five 1-mm-diameter glass beads and one 2-mm-diameter glass bead (except for samples processed in the Diagnostic Service Laboratory, where Lysing matrix A with two ceramic beads instead of the glass beads was used). AP1 buffer $(400 \mu \mathrm{l})$ from the Qiagen Plant DNeasy mini kit (Qiagen) was added to each of the 2-ml lysing tubes and the mixture was homogenized in a FastPrep FP120 instrument (MP Bio) twice at speed setting 6 for $40 \mathrm{~s}$. After homogenization, AP2 buffer $(130 \mu \mathrm{l})$ was added to each tube and tubes were cooled on ice for $5 \mathrm{~min}$, then spun at $16,000 \times g$ for $6 \mathrm{~min}$. Subsequent DNA purification steps were performed as per the manufacturer's instruction. DNA concentration was measured using the Quant-iT 
dsDNA high-sensitivity assay kit (Invitrogen) on a 96-well SAFIRE microplate reader (TECAN).

Copy number of rDNA in $\boldsymbol{F}$. virguliforme. Three single-copy genes- $\beta$-tubulin (HM453328.1), G3PD (glyceraldehyde 3-phosphate dehydrogenase), and FvToxin-1 (JF440964.1) —were selected as single-copy reference genes to determine the rDNA copy numbers among $F$. virguliforme isolates collected from multiple soybean fields. These genes were confirmed as single copy by BLASTn search against the $F$. virguliforme genome sequence (41). Primers specific to each of these three genes were designed using Primer Express 3.0 (Applied Biosystems) (Table 2). The PCR efficiency of these three primer sets was evaluated by running a fivefold serial dilution of $F$. virguliforme genomic DNA ranging from $10 \mathrm{ng}$ to $1 \mathrm{pg}$. Quantification of the rDNA and the three single-copy genes was performed using SYBR green based qPCR, which consisted of $10 \mu$ of $2 \times$ SYBR Green PCR Master Mix (Life Technologies), $0.5 \mu \mathrm{l}$ of each primer $(20 \mu \mathrm{M}), 0.2 \mu \mathrm{l}$ of BSA $(20 \mathrm{mg} / \mathrm{ml})$, and distilled water (Gibco) to a total-volume of $20 \mu \mathrm{l}$ in duplicate for each template DNA. Several genotypes were identified in a multilocus genotyping study of $F$. virguliforme (J. Wang and M. I. Chilvers, unpublished data). Therefore, to maximize the genetic diversity among the tested $F$. virguliforme isolates, multiple isolates from different genotype groups were included in the rDNA copy number variation test. PCR cycling conditions were set at 1 cycle at $95^{\circ} \mathrm{C}$ for 10 min followed by 40 cycles of $15 \mathrm{~s}$ at $95^{\circ} \mathrm{C}$ and $60 \mathrm{~s}$ at $60^{\circ} \mathrm{C}$ (fluorescent signal was collected at this stage). After the qPCR cycling stage, the melt curve stage was performed to determine the specificity of each primer set. The melt curve stage parameter was set as one step with $15 \mathrm{~s}$ at $95^{\circ} \mathrm{C}$ for dissociation, $60 \mathrm{~s}$ at $60^{\circ} \mathrm{C}$ for reassociation, and increase the temperature from 60 to $95^{\circ} \mathrm{C}$ with $0.3^{\circ} \mathrm{C}$ increments using the step and hold method.

Real-time PCR assay cross-laboratory and platform validation. Specificity and sensitivity of the qPCR assay was evaluated on a different platform, in collaboration with Michigan State University's Diagnostic Services Laboratory. The qPCR assay was performed on the Cepheid SmartCycler real-time PCR system (Cepheid, Sunnyvale, CA), in a $20-\mu$ l total volume with two technical repeats. The qPCR master mix and cycling conditions were the same as previously described and sensitivity was evaluated with serially diluted $F$. virguliforme genomic DNA from $10 \mathrm{ng}$ to $10 \mathrm{fg}$ with a 1:10 dilution factor. Specificity of this assay was tested against closely related Fusarium spp. (F. tucumaniae, $F$. brasiliense, F. phaseoli, F. crassistipitatum, and F. cuneirostrum). Additionally, soybean samples from commercial fields submitted for disease diagnosis were tested with this assay. DNA extraction from soybean samples was performed as described above.

Data analyses. Real-time PCR data were collected and analyzed using StepOne Software v2.3. qPCR standard curve plots and DNA concentration correlations were plotted using the $\mathrm{R}$ ggplot2 package (42). The limit of detection was determined by $100 \%$ amplification of the lowest amount of target genomic DNA (8). Statistical analysis was performed with the R stats package.

\section{RESULTS}

Assay design and in silico screening. Based on the multiple sequence alignment conducted with MUSCLE, two polymorphic regions were identified as candidates for design of $F$. virguliforme specific assays. One of the polymorphic regions (from 481 to $777 \mathrm{bp}$ ) has a self-repeat (from 1,736 to $2,034 \mathrm{bp}$ ) in the IGS rDNA region (Supplemental Figure 1). Primers designed on the self-repeat region were determined to be less specific to $F$. virguliforme because of the ambiguous nucleotide mismatches with the self-repeat region. Instead, the other polymorphic region (between 1.2 and $1.4 \mathrm{~kb}$ ) of the IGS rDNA with moderate polymorphism did not have any self-repeats and was chosen as the target to design primers and probes for the final assay. Multiple primers $(n=35)$ and dual-labeled probes $(n=5)$ were designed on the polymorphic sites. Before testing primer sets, the secondary structure of the designed PCR assay amplicons were predicted using the mfold (45) web server under PCR annealing conditions. The best amplicon candidates had higher free energy and fewer stem-loop structures, as demonstrated in the assay (Supplemental Figure 2).

Specificity and sensitivity of real-time PCR. In total, 30 primers and six probes were tested during assay development.

TABLE 2. Primers for determining ribosomal DNA intergenic spacer copy number variation

\begin{tabular}{|c|c|c|c|c|c|}
\hline Names $^{a}$ & Sequences $\left(5^{\prime}-3^{\prime}\right)$ & Length $(\mathrm{nt})^{\mathrm{b}}$ & $\operatorname{Tm}\left({ }^{\circ} \mathrm{C}\right)^{\mathrm{c}}$ & PCR efficiency (\%) & Amplicon size (bp) \\
\hline gpd_F & CTTGATGGCCTGCTTGATCTC & 21 & 58.5 & 94.72 & 74 \\
\hline gpd_R & ACGTCTCCGTTGTCGACCTTA & 21 & 58.3 & & \\
\hline b-tub_F & CTGCAGCAGCTTCATCATGAG & 21 & 58.4 & 99.36 & 67 \\
\hline FvTox1_F & CAACAACACCCATCGCTAACG & 21 & 60.0 & 95.12 & 68 \\
\hline FvTox1_R & GGGAGGACCCCAGTTTTCC & 19 & 59.2 & $\ldots$ & $\ldots$ \\
\hline
\end{tabular}

${ }^{a}$ Abbreviations: gpd = designed based on the Fusarium virguliforme glyceraldehyde 3-phosphate dehydrogenase gene, $b$-tub $=$ designed based on the $\beta$-tubulin gene, FvTox $1=$ designed based on the FvTox 1 gene, and FvTox $1=$ phytotoxin gene.

$\mathrm{b}$ Length in nucleotides.

${ }^{\mathrm{c}}$ Melting temperature $(\mathrm{Tm})$ values were calculated using ABI PrimerExpress $3.0(\mathrm{ABI})$ —Primer Probe Test Tool.

TABLE 3. Primers and probes used in the quantitative polymerase chain reaction (qPCR) quantification assays

\begin{tabular}{|c|c|c|c|}
\hline Names & Sequences $\left(5^{\prime}-3^{\prime}\right)$ & Length (nt) ${ }^{\mathrm{a}}$ & $\operatorname{Tm}\left({ }^{\circ} \mathrm{C}\right)^{\mathrm{b}}$ \\
\hline F6-3,e,f & GTAAGTGAGATTTAGTCTAGGGTAGGTGAC & 30 & 57.8 \\
\hline $\mathrm{R}^{\mathrm{c}, \mathrm{f}}$ & GGGACCACCTACCCTACACCTACT & 24 & 59.6 \\
\hline FvPrb-3, $3^{c, f}$ & 6FAM-TTTGGTCTAGGGTAGGCCG-MGBNFQ & 19 & 70.0 \\
\hline HHIC-F ${ }^{d}$ & CTAGGACGAGAACTCCCACAT & 21 & 54.6 \\
\hline HHIC-R ${ }^{\mathrm{d}}$ & CAATCAGCGGGTGTTTCA & 18 & 55.0 \\
\hline HHIC-prb ${ }^{d}$ & 5HEX-TCGGTGTTGATGTTTGCCATGGT-3IABkFQ & 23 & 65.2 \\
\hline
\end{tabular}

a Length in nucleotides.

${ }^{\mathrm{b}}$ Melting temperature (Tm) values were calculated using ABI PrimerExpress 3.0—Primer Probe Test Tool.

${ }^{c}$ Primers and probes developed in this study.

${ }^{\mathrm{d}}$ Primers and probes developed by Haudenshield and Hartman (16).

e Primers used for conventional PCR assay.

${ }^{\mathrm{f}}$ Primers and probes used for qPCR assay. 
One primer set (F6-3 and R6) (Table 3) amplifying a 76-bp product from $F$. virguliforme and one TaqMan probe (FvPrb-3) (Table 3) were determined to be the most specific and sensitive primer and probe combination. The qPCR assay detected all tested target $F$. virguliforme strains at $100 \mathrm{pg}$ of DNA with a $\mathrm{Ct}$ value range between 20.53 and 21.78, while the $\mathrm{Ct}$ value for the other nontarget species were all above the preset $\mathrm{Ct}$ values of the lower limit of detection $(\mathrm{LOD}-\mathrm{Ct}=30)($ Table 1$)$. There was a linear relationship $\left(y=-3.3 x+36, R^{2}=0.996\right)$ between $F$. virguliforme genomic DNA serial dilutions (log transformed) and $\mathrm{Ct}$ values, and the corresponding PCR efficiency was 99\% (Fig. 1). The genomic DNA serial dilution standard curve indicated that the qPCR assay consistently detected $10 \mathrm{fg}$ of $F$. virguliforme

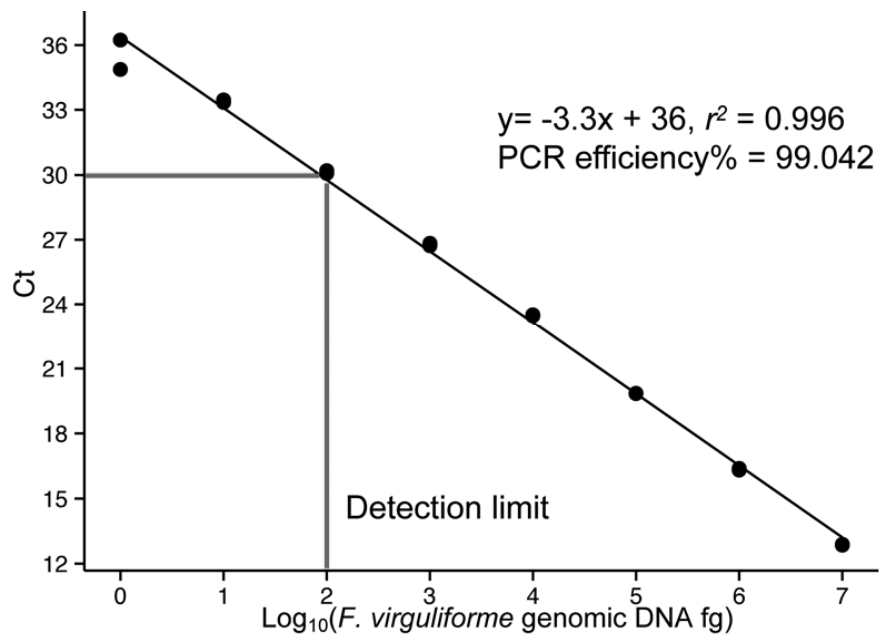

Fig. 1. Standard curve for absolute quantification of Fusarium virguliforme genomic DNA (fg). Genomic DNA samples were prepared from pure cultures grown in broth. The detection limit for pure culture genomic DNA was $100 \mathrm{fg}$. Two technical repeats for each $F$. virguliforme genomic DNA dilution level. $\mathrm{PCR}=$ polymerase chain reaction.

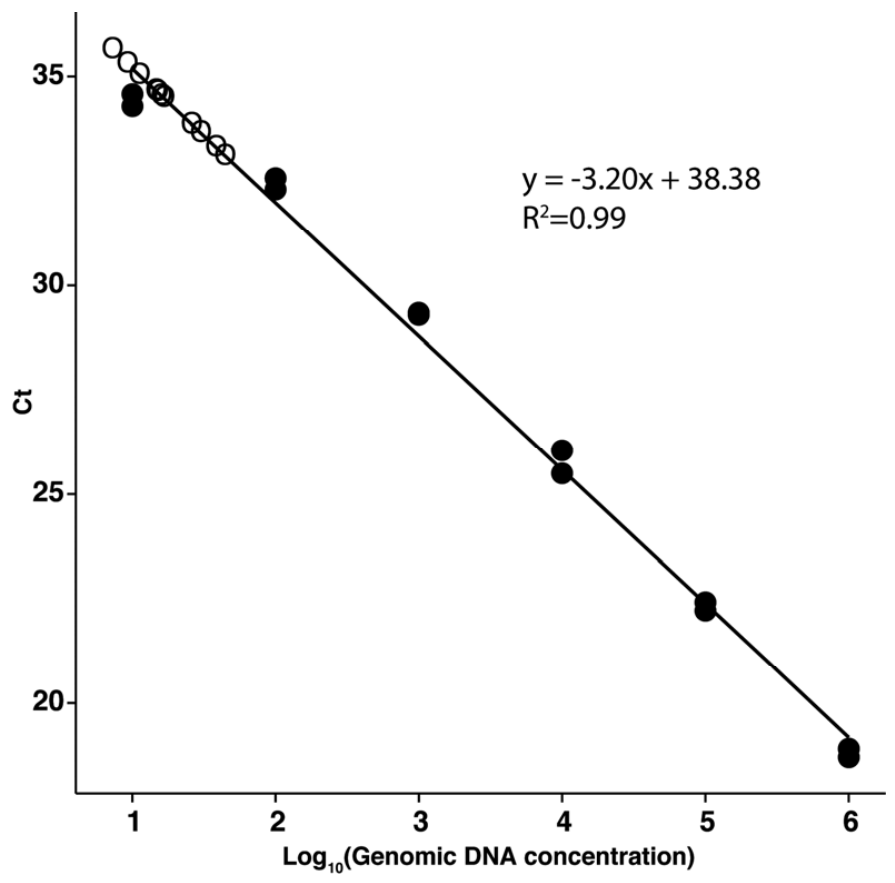

Fig. 2. Quantitative polymerase chain reaction standard curve plotted with serially diluted Fusarium virguliforme genomic DNA (log transformed) in fentograms against cycle threshold values with solid circles, open circles indicate nontarget species as indicated in Table 1 . Sensitivity of the assay was determined to be $100 \mathrm{fg}$ of $F$. virguliforme genomic DNA. genomic DNA $(\mathrm{Ct}=33.2)$. The cut-off $\mathrm{Ct}$ value threshold for positive amplification was set at $100 \mathrm{fg}$ of $F$. virguliforme genomic DNA to remove nonspecific background amplifications (Fig. 2). In the artificially inoculated soil samples, our qPCR assay consistently detected 100 conidia artificially inoculated in 0.5-g soil samples (Fig. 3).

Conventional PCR assay. The conventional PCR assay developed is specific to $F$. virguliforme, amplifying a 375-bp DNA fragment. The conventional PCR was specific to $F$. virguliforme except for weak amplification of two nontarget Fusarium spp., $F$. crassistipitatum and $F$. brasiliense (product size $=375 \mathrm{bp}$ ). To overcome the nonspecific amplifications, the annealing temperature was raised from 60 to $65^{\circ} \mathrm{C}$, which successfully eliminated amplification of these nontarget species (Supplemental Figure 3). The detection limit of the conventional PCR was determined to be $1 \mathrm{pg}$ of $F$. virguliforme genomic DNA (Supplemental Figure 4).

Validation of real-time PCR assay and conventional PCR assay. Both conventional PCR and real-time PCR were used to diagnose soybean plants collected from commercial soybean fields in Michigan from 2011 to 2013. Based on the diagnostic results (Table 4), SDS-like symptomatic soybean plants were not always associated with the positive detection of $F$. virguliforme DNA from soybean root tissues. For example, samples collected from Midland County, MI (Midland-12-02) in 2012 were detected to be SDS negative but tested positive for $P$. gregata, the causal agent of BSR, with the BSR diagnostic qPCR assay (27). However, three plant samples with nontypical SDS foliar interveinal symptoms (MISO2-3, GR-12-02, and SA-11-2a) were determined to have positive $F$. virguliforme infection $(\mathrm{Ct}$ values $<30)$. Using the conventional PCR assay, most plant samples (27 of 38) were diagnosed with definitive results, as indicated with intense bands. However, the sensitivity of the conventional PCR assay was limited, potentially causing false-negative results for 11 of 38 samples. In contrast, the qPCR assay gave unambiguous diagnostic results by simultaneously utilizing quantitative $\mathrm{Ct}$ values and a reliable exogenous control assay. In diagnostic samples with abundant $F$. virguliforme DNA, the exogenous control may perform abnormally (e.g., no exponential amplification or early amplifications). The exogenous control assay began to be affected when the $F$. virguliforme genomic DNA reached $1 \mathrm{pg}$ or more in the diagnostic samples (Supplemental Figure 5).

rDNA IGS copy number variation between isolates. Amplification efficiencies of the three single-copy genes were all very similar at 95, 99, and 95\% for the G3PD, $\beta$-tubulin, and FvTox1

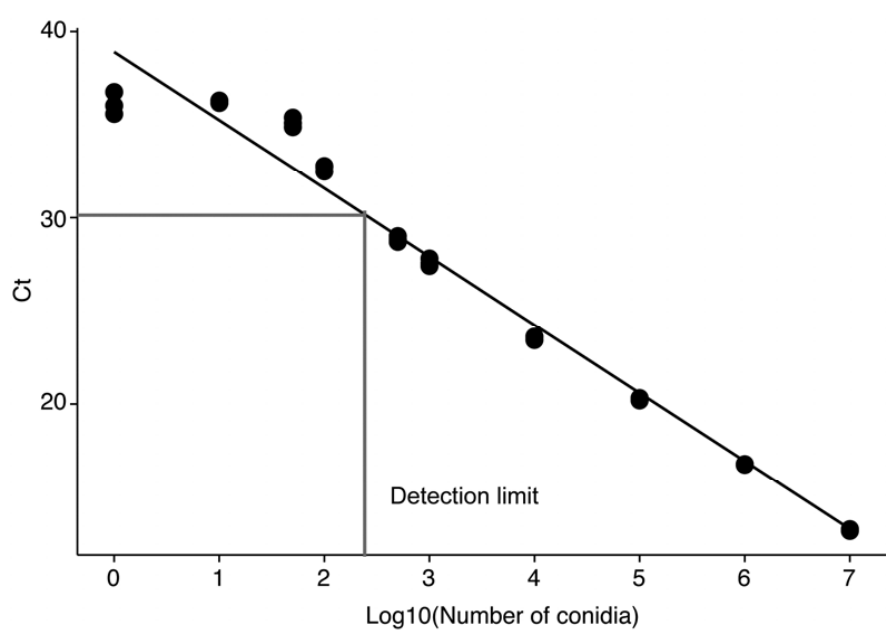

Fig. 3. Quantitative polymerase chain reaction (qPCR) quantification of DNA samples isolated from artificially inoculated soil samples with serially diluted Fusarium virguliforme macroconidia suspension. Detection limit was 100 macroconidia per $0.5 \mathrm{~g}$ of soil. Total soil DNA were isolated from six soil sample replicates, and qPCR was run twice for each soil DNA sample. 
assays, respectively. Less than 5\% difference in efficiency exists between the qPCR assay and the single-copy gene assays, indicating a valid rDNA copy number analysis. Melt curve analysis of the SYBR green PCR product detected a single peak for each primer set, demonstrating amplification of a single product. The PCR efficiency of the qPCR assay was calculated using the formula IGS copy $=(1+0.994)^{\Delta \mathrm{Ct}}$, (e.g., $\Delta \mathrm{Ct}$ is the difference between $\mathrm{Ct}$ values of two amplified genes), given the PCR efficiency of $99.36 \%$. The IGS rDNA copy numbers of $F$. virguliforme ranged from 138 to 233, with an average of 208 per haploid genome (Table 5).

qPCR assay cross-laboratory and platform validation. The qPCR assay performed similarly on both platforms tested. Assay sensitivity was determined to be $100 \mathrm{fg}$ of $F$. virguliforme DNA and the assay was determined to be specific to this species. PCR efficiency of the $F$. virguliforme qPCR assay on the SmartCycler real-time PCR system and the StepOnePlus real-time PCR system was 99.8 and $99.0 \%$, respectively. Diagnostic samples (16 soybean and 1 dry bean) were submitted from 14 counties in Michigan; 8 samples were diagnosed as positive for $F$. virguliforme with the qPCR assay (Table 6). Of the 17 diagnostic samples tested on the SmartCycler system, 4 were also tested on the StepOnePlus system, producing comparable results. Ct values of
DNA samples extracted from taproot versus lateral root were not significantly different $(P>0.05)$.

\section{DISCUSSION}

Soybean SDS is a major threat to soybean production in the United States. Specific and sensitive molecular diagnostic assays are lacking, which hampers diagnosis and limits epidemiological studies of the disease. To address this need, we developed a specific and sensitive qPCR assay to quantify $F$. virguliforme in soybean tissue, soil, and environmental samples. The assay was specific to $F$. virguliforme when tested against closely related Fusarium spp. and other commonly encountered fungi in soybean fields. The assay is very sensitive and can detect as little as $100 \mathrm{fg}$ of $F$. virguliforme genomic DNA or 100 macroconidia per halfgram of soil. An exogenous control was multiplexed with the $F$. virguliforme assay to detect false negatives and monitor for the presence of PCR inhibitors. In addition, the assay was validated with soybean samples collected from commercial soybean fields. The qPCR assay is transferable and successfully performed on a Cepheid SmarterCycler real-time PCR platform at the NorthCentral region's hub laboratory of the National Plant Diagnostic Network.

TABLE 4. Diagnostic results for commercial soybean samples on StepOnePlus real-time polymerase chain reaction (PCR) system

\begin{tabular}{|c|c|c|c|c|c|c|c|c|c|}
\hline Sample ID & County $^{\mathrm{b}}$ & Isol $^{\mathrm{c}}$ & CPCR & qPCR & $\mathrm{Fv} \mathrm{Ct}^{\mathrm{d}}$ & $\mathrm{Fv} \mathrm{Ct} 2$ & $\mathrm{HHIC} \mathrm{Ct} 1^{\mathrm{e}}$ & $\mathrm{HHIC} \mathrm{Ct} 2$ & Description of symptoms ${ }^{f}$ \\
\hline Coleman & Midland & NEG & POS & POS & 15.64 & 14.90 & UD & UD & Foliar SDS symptoms, leaf chlorosis and necrosis \\
\hline Razjer & Van Buren & NEG & NEG & NEG & UD & UD & UD & UD & Root rot \\
\hline Avery & Van Buren & NEG & $?$ & POS & 29.48 & 31.36 & 29.48 & 28.64 & SDS-like foliar symptoms \\
\hline EA-13-1 & Eaton & POS & POS & POS & 31.42 & 29.55 & 28.26 & 28.21 & SDS-like foliar symptoms discoloration of taproot \\
\hline MtC-13-1 & Montcalm & POS & POS & POS & 29.59 & 27.76 & 28.23 & 28.15 & SDS-like foliar symptoms \\
\hline IN-13-1 & Ingham & NEG & NEG & NEG & 32.78 & 31.31 & 28.10 & 28.09 & White mold symptoms and chlorosis on leaves \\
\hline MISO2-7 & Midland & NEG & NEG & NEG & 31.38 & 31.27 & 29.42 & 29.47 & $\begin{array}{l}\text { Foliar symptom on the lower part plant, } \\
\text { possible herbicide }\end{array}$ \\
\hline CL-12-01 & Clinton & NEG & NEG & NEG & 34.97 & 33.44 & 29.04 & 29.31 & Foliar SDS-like symptom, but not typical \\
\hline IO-12-01 & Ionia & NEG & NEG & NEG & 34.62 & 33.55 & 29.25 & 29.23 & Foliar chlorosis symptom \\
\hline EA-12-01 & Eaton & NEG & $?$ & NEG & 32.33 & 32.28 & 29.08 & 29.21 & no SDS foliar symptoms \\
\hline TU-12-01 & Tuscola & NEG & $?$ & NEG & 32.93 & 30.88 & 29.27 & 29.18 & Manganese deficiency symptoms \\
\hline GR-12-01 & Gratiot & POS & POS & POS & 31.34 & 24.15 & 29.34 & 28.93 & Typical SDS-like symptoms, wilting \\
\hline IS-12-01 & Isabella & NEG & NEG & NEG & 34.67 & 34.52 & 29.16 & 28.99 & no SDS foliar symptoms \\
\hline MISO2-3 & Allegan & NEG & POS & POS & 29.68 & 26.78 & 29.22 & 29.06 & Both oomycete and fungal wilting symptom \\
\hline IN-12-01 & Ingham & NEG & NEG & NEG & 33.18 & 35.22 & 29.20 & 29.39 & $\begin{array}{l}\text { Interveinal chlorosis, lack of hairy roots, may be } \\
\text { BSR pith dark brown, but BSR assay negative }\end{array}$ \\
\hline GR-12-02 & Gratiot & NEG & POS & POS & 33.09 & 27.96 & 29.22 & 28.95 & Wilting and leaves chlorosis \\
\hline Midland-12-02 & Midland & NEG & $?$ & NEG & 35.52 & 34.88 & 29.29 & 29.13 & $\begin{array}{l}\text { SDS-like foliar symptoms, brown pith, BSR assay } \\
\text { positive }\end{array}$ \\
\hline DL201203875 & Monroe & POS & POS & POS & 18.59 & - & UD & - & Brown stem, leaves discoloration \\
\hline EA-12-02 & Eaton & NEG & $?$ & NEG & 32.71 & 31.7 & 29.13 & 29.236 & Phytoplasma symptoms, but no SDS symptoms \\
\hline SA-11-2a & Saginaw & POS & POS & POS & 20.55 & - & $* 23.24$ & - & Plant wilting, defoliation, and Dead \\
\hline SA-11-2b & Saginaw & NEG & POS & POS & 21.16 & - & UD & - & Foliar SDS-like symptom \\
\hline HU-11-1b & Huron & POS & POS & POS & 21.50 & - & UD & - & Foliar SDS-like symptom \\
\hline HU-11-1 (DL-6) & Huron & POS & POS & POS & 21.89 & - & $* 23.90$ & - & Foliar SDS-like symptom \\
\hline DL-5 & Lenawee & POS & POS & POS & 20.21 & 20.83 & UD & UD & Foliar SDS-like symptom \\
\hline SA-11-1 & Saginaw & POS & POS & POS & 24.32 & 25.84 & 28.18 & 27.766 & Foliar SDS-like symptom \\
\hline CL-11-1 & Clinton & POS & POS & POS & 24.00 & - & $* 26.97$ & - & N/A \\
\hline GR-11-2b & Gratiot & POS & POS & POS & 28.22 & - & 28.2 & - & Foliar SDS-like symptom \\
\hline CL-11-2 & Clinton & NEG & POS & POS & 28.23 & - & 28.09 & - & N/A \\
\hline GR-11-2a & Gratiot & NEG & POS & POS & 28.03 & - & 28.31 & - & Plant Defoliation and Dead \\
\hline IN-11-1 & Ingham & NEG & POS & POS & 29.75 & - & 29.29 & - & Foliar SDS-like symptom \\
\hline TUS-11-2a & Tuscola & NEG & $?$ & NEG & 33.58 & - & 28.43 & - & Leaf burn/ herbicide/desiccant damage \\
\hline TUS-11-2b & Tuscola & NEG & $?$ & NEG & 33.38 & - & 28.09 & - & Foliar SDS-like symptom \\
\hline TUS-11-1b & Tuscola & NEG & $?$ & NEG & 33.85 & - & 28.08 & - & Stunted beans/yellowing/root rot \\
\hline HU-11-2 & Huron & NEG & $?$ & NEG & 32.55 & - & 28.34 & - & SDS-like symptoms \\
\hline TUS-11-1a & Tuscola & NEG & $?$ & NEG & 33.79 & - & 28.18 & - & N/A \\
\hline DL-4 & Kalamazoo & NEG & $?$ & NEG & 34.71 & 33.94 & 28.32 & 28.476 & Foliar SDS-like symptom \\
\hline TUS-11-3 & Tuscola & NEG & NEG & NEG & 34.35 & -- & 28.14 & -- & Foliar SDS-like symptom \\
\hline
\end{tabular}

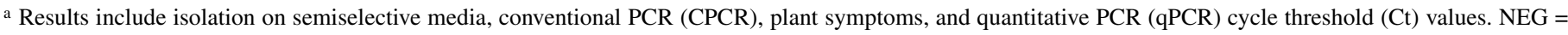
negative results, $\mathrm{POS}=$ positive results, $\mathrm{UD}=$ undetected, ? = unclear results (i.e., weak band), and $-=$ not applicable.

b County in Michigan from which samples were collected.

c Positive isolation (Isol) was identified by colony morphology.

d Two DNA extractions were made for qPCR detection.

e Internal control to assess the potential PCR inhibitors; * indicates abnormal Ct values affected by $F$. virguliforme assay competition.

f $\mathrm{SDS}=$ sudden death syndrome and BSR = brown stem rot. 
The choice of genetic locus and in silico sequence analysis plays a pivotal role in development and performance of a qPCR assay. Revision of the taxonomy of Fusarium spp. that cause SDS or BRR has resulted in the obsolescence of previously developed assays. However, the taxonomic revision and loci used for phylogeny construction also provided an opportunity for the development of more specific diagnostic assays. The phylogenetic tree constructed with IGS rDNA sequences explicitly separated the Fusarium spp. in the SDS-BRR clade with high branch support (33). Therefore, the IGS rDNA was determined to be a suitable target locus to design an assay for the specific detection of $F$. virguliforme. The multicopy nature of the IGS rDNA target was also desirable from the standpoint of assay specificity.

An optimized multiple sequence alignment is essential for identifying suitable polymorphic regions within a locus for speciesspecific primer and probe design. Different sequence alignment methods (MUSCLE, MAFFT, ClustalW, and T-Coffee) were used to align the IGS rDNA sequence of SDS-BRR clade Fusarium spp. The multiple sequence alignments of the IGS rDNA loci required the insertion of a considerable number of gaps, which increased the complexity of the alignment. Alignments with ClustalW (22) and T-Coffee (31) resulted in alignments that were not optimal for locating polymorphic loci. However, the use of methods such as MUSCLE (11) and MAFFT (20) resulted in the identification and validation of polymorphisms suitable for specific species discrimination.

Sensitivity is also a significant factor that determines the applicability of a qPCR assay. For the previous qPCR assays designed for $F$. virguliforme, two targeted the small subunit of the mtDNA and the other was designed on the FvToxl toxin-coding gene $(14,24,29)$. Although the limit of detection for the mtDNA assays was $90 \mathrm{fg}$ of genomic DNA, these two assays are not specific to $F$. virguliforme based on the discovery of four SDS and three BRR Fusarium pathogens $(4,5)$. The assay designed to the FvToxl is specific; however, the assay is not as sensitive, because it requires $25 \mathrm{pg}$ of genomic DNA. We designed our qPCR assay to the IGS rDNA region, and the limit of detection was determined to be $100 \mathrm{fg}$ of genomic DNA (approximately equivalent to the DNA quantity of four haploid genomes of $F$. virguliforme), which is 100 times more sensitive than the single-copy FvToxl gene assay.

rDNA copy number variation and IGS rDNA sequence variation among isolates have been reported in several fungal species $(2,6,18)$. Variation in rDNA copy number within species may cause variability in qPCR assay sensitivity. IGS rDNA sequence variation within species may affect the specificity of the qPCR assay as well. In this study, we tested our qPCR assay with numerous isolates of $F$. virguliforme obtained from isolates representing the primary genetic groups (J. Wang and M. I. Chilvers, unpublished data) from geographically distant locations within the United States. Although the rDNA copy number ranged from 138 to 233 , with an average number of 208 copies per haploid genome, the largest difference in $\mathrm{Ct}$ value was 0.76 cycles, which is within the same order of magnitude. Therefore, the differences in rDNA IGS copy numbers did not cause significant differences in qPCR quantification or diagnostic detection.

Although improved sensitivity and specificity are ideal, consistent performance in dealing with real-world diagnostic soybean samples was of primary concern. The molecular diagnostic assay results are strong evidence in determining a diagnostic conclusion, especially when the submitted plant samples lack other specific symptoms or signs. Because of PCR inhibitors in plant DNA or plant tissue sampling bias, the molecular diagnostic assay detection results can be inconsistent (Table 5). To avoid the potential inconsistent detection of $F$. virguliforme during diagnostics, we implemented PCR additives (e.g., BSA), which alleviated the PCR inhibition effects. Multiple $(n \geq 2)$ biological and technical repeats are recommended to improve consistency in the diagnostic assay. Normally, without competition or inhibition, the HHIC exogenous control assay will produce a Ct value of 29 . However, inhibitors in the DNA samples can prevent PCR amplification for the $F$. virguliforme assay and exogenous control assay. To overcome the PCR inhibition issues, magnetic beadbased DNA sample purification can be used to reduce PCR inhibitors in DNA samples. Furthermore, PCR inhibitions are not the only cause for lack of amplification in the exogenous control assay. Too much $F$. virguliforme genomic DNA in the sample can also cause no amplification or malfunction of the HHIC exogenous control assay. When the $F$. virguliforme genomic DNA reaches $1 \mathrm{pg}$ in the reaction, the HHIC exogenous control assay is affected. Therefore, interpretations of the HHIC exogenous control results help evaluate the performance of the $F$. virguliforme assay.

Stable performance across labs is one of the most important criteria of a qPCR diagnostic assay. The performance of a qPCR assay can be vulnerable to changes in the PCR reagents or realtime PCR systems (17). It may require efforts to optimize the qPCR conditions to perform a robust qPCR assay with the desired performance. Use of a qPCR assay on a new platform, change in PCR master mix, or use in a new lab should always be implemented with the appropriate validation. To explore the applicability of our qPCR assay on another real-time PCR systems, we

TABLE 5. Fusarium virguliforme ribosomal DNA (rDNA) intergenic spacer (IGS) copy number estimation using three single copy reference genes

\begin{tabular}{|c|c|c|c|c|c|}
\hline \multirow[b]{2}{*}{ Isolates $^{\mathrm{a}}$} & \multicolumn{3}{|c|}{ Mean Ct difference between IGS and single-copy gene ${ }^{b}$} & \multirow[b]{2}{*}{ Mean Ct difference ${ }^{c}$} & \multirow[b]{2}{*}{ Copy number ${ }^{\mathrm{d}}$} \\
\hline & Btub-IGS & FvTox1-IGS & G3PD-IGS & & \\
\hline INMO_A6 & 7.57 & 7.64 & 7.66 & 7.62 & 190 \\
\hline INMO_C5 & 7.69 & 7.53 & 7.76 & 7.66 & 195 \\
\hline KSSH_E5 & 7.83 & 7.54 & 7.84 & 7.74 & 205 \\
\hline MIBer_A6 & 7.59 & 7.51 & 7.71 & 7.60 & 187 \\
\hline MIBer_B7 & 7.76 & 7.56 & 7.83 & 7.72 & 202 \\
\hline MIBer_E1 & 7.99 & 7.76 & 8.02 & 7.92 & 233 \\
\hline MIIN_B7 & 7.89 & 7.67 & 7.93 & 7.83 & 219 \\
\hline MISA_C4 & 7.30 & 7.26 & 7.50 & 7.36 & 158 \\
\hline MISTJ_E4a & 7.80 & 7.71 & 8.06 & 7.86 & 223 \\
\hline MISTJ_G5 & 8.02 & 7.66 & 8.04 & 7.91 & 231 \\
\hline MITU_B4 & 7.90 & 7.79 & 8.03 & 7.91 & 231 \\
\hline MIVB_A5 & 7.21 & 7.02 & 7.25 & 7.16 & 138 \\
\hline 22292-Mont1 & 7.54 & 7.56 & 7.87 & 7.66 & 194 \\
\hline
\end{tabular}

${ }^{a}$ F. virguliforme isolates collected from Indiana (INMO), Kansas (KSSH), and Michigan (MIBer, MIIN, MISA, MISTJ, MITU, and MIVB).

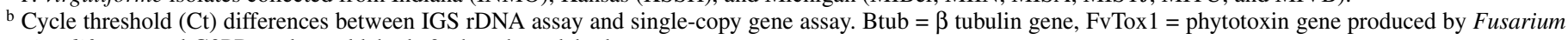
virguliforme, and $\mathrm{G} 3 \mathrm{PD}=$ glyceraldehyde 3-phosphate dehydrogenase gene.

c Average $\mathrm{Ct}$ for all three single copy genes.

d Copy number determined by mean Ct differences. 
TABLE 6. Soybean and dry beans samples submitted to Michigan State University Diagnostic Services Laboratory for diagnosis assayed on a SmartCycler realtime polymerase chain reaction system

\begin{tabular}{|c|c|c|c|c|c|}
\hline Sample ID & Root parts $^{\mathrm{a}}$ & County ${ }^{\mathrm{b}}$ & Dilution $^{\mathrm{c}}$ & $\mathrm{Ct}^{\mathrm{d}}$ & Results \\
\hline \multirow[t]{3}{*}{2192} & Lateral & Branch & 1 & 19.32 & Positive \\
\hline & Lateral & Branch & $1: 10$ & 22.74 & $\ldots$ \\
\hline & Tap & Branch & 1 & 14.12 & $\ldots$ \\
\hline \multirow[t]{4}{*}{2193} & Lateral & Branch & 1 & 29.22 & Positive \\
\hline & Lateral & Branch & $1: 10$ & 33.25 & $\ldots$ \\
\hline & Tap & Branch & 1 & 26.31 & $\ldots$ \\
\hline & Tap & Branch & $1: 10$ & 29.73 & $\ldots$ \\
\hline & Tap & Lenawee & 1 & 23.24 & $\ldots$ \\
\hline & Tap & Lenawee & $1: 10$ & 27.11 & $\ldots$ \\
\hline \multirow[t]{4}{*}{2371} & Lateral & Hillsdale & 1 & 19.44 & Positive \\
\hline & Lateral & Hillsdale & $1: 10$ & 23.17 & $\ldots$ \\
\hline & Tap & Hillsdale & 1 & 22.32 & $\ldots$ \\
\hline & Tap & Hillsdale & $1: 10$ & 26.09 & $\ldots$ \\
\hline $2905^{\mathrm{e}}$ & Lateral & Huron & 1 & 37.99 & Negative \\
\hline & Lateral & Allegan & $1: 10$ & 23.97 & $\ldots$ \\
\hline & Tap & Allegan & 1 & 19.66 & $\ldots$ \\
\hline & Tap & Allegan & $1: 10$ & 23.51 & $\ldots$ \\
\hline \multirow[t]{4}{*}{2603} & Lateral & Shiawasee & 1 & UD & Negative \\
\hline & Lateral & Shiawasee & $1: 10$ & UD & $\ldots$ \\
\hline & Tap & Shiawasee & 1 & UD & $\ldots$ \\
\hline & Tap & Shiawasee & $1: 10$ & UD & $\ldots$ \\
\hline \multirow[t]{4}{*}{2591} & Lateral & Clinton & 1 & UD & Negative \\
\hline & Lateral & Clinton & $1: 10$ & UD & $\ldots$ \\
\hline & Tap & Clinton & 1 & UD & $\ldots$ \\
\hline & Tap & Clinton & $1: 10$ & UD & \\
\hline \multirow[t]{3}{*}{3059} & Lateral & Ingham & 1 & 18.97 & Positive \\
\hline & Lateral & Ingham & $1: 10$ & 23.07 & $\ldots$ \\
\hline & Tар & Ingham & 1 & 19.36 & $\ldots$ \\
\hline \multirow[t]{4}{*}{3415} & Lateral & Tuscola & 1 & 35.25 & Negative \\
\hline & Lateral & Tuscola & $1: 10$ & 38.65 & $\ldots$ \\
\hline & Tap & Tuscola & 1 & 37.56 & $\ldots$ \\
\hline & Tap & Tuscola & $1: 10$ & UD & $\ldots$ \\
\hline 3505 & Lateral & Van Buren & 1 & 18.98 & Positive \\
\hline & Lateral & Van Buren & $1: 10$ & 22.28 & $\ldots$ \\
\hline & Tap & Van Buren & 1 & 17.48 & $\ldots$ \\
\hline & Tap & Van Buren & $1: 10$ & 20.45 & $\ldots$ \\
\hline 3525 & Lateral & Saginaw & 1 & UD & Negative \\
\hline & Lateral & Saginaw & $1: 10$ & UD & $\ldots$ \\
\hline & Tap & Saginaw & 1 & 37.97 & $\ldots$ \\
\hline & Tap & Saginaw & $1: 10$ & UD & $\ldots$ \\
\hline 3851 & Lateral & Lapeer & 1 & 31.08 & Negative \\
\hline & Lateral & Lapeer & $1: 10$ & 35.28 & $\ldots$ \\
\hline & Tap & Lapeer & 1 & 31.48 & $\ldots$ \\
\hline & Tap & Lapeer & $1: 10$ & 34.21 & $\ldots$ \\
\hline 3872 & Lateral & Arenac & 1 & UD & Negative \\
\hline & Lateral & Arenac & $1: 10$ & UD & $\ldots$ \\
\hline & Tар & Arenac & 1 & 39.22 & $\ldots$ \\
\hline & Tap & Arenac & $1: 10$ & UD & $\ldots$ \\
\hline 4532 & Lateral & Lenawee & 1 & 26.73 & Positive \\
\hline & Lateral & Lenawee & $1: 10$ & 31.16 & $\ldots$ \\
\hline & Tap & Lenawee & 1 & 36.86 & $\ldots$ \\
\hline & Tap & Lenawee & $1: 10$ & UD & $\ldots$ \\
\hline
\end{tabular}

${ }^{a}$ Root portion used for DNA extraction.

b Michigan county.

${ }^{c}$ DNA dilution level from the original DNA extraction.

${ }^{\mathrm{d}} \mathrm{Ct}=$ cycle threshold and $\mathrm{UD}=$ undetected.

e Dry bean samples. 
collaborated with the Michigan State University Diagnostic Services Laboratory. Assay performance was tested on a Cepheid SmartCycler real-time PCR system, which is the most popular system in the North-Central region of the National Plant Diagnostic Network. Without changing the reagents or cycling parameters, this assay successfully achieved the desired performance (specificity, sensitivity, and PCR efficiency), demonstrating high transferability of this assay between platforms. In addition, the Michigan State University Diagnostic Services Laboratory used this assay for the diagnostic evaluation of soybean and dry bean plants with SDS or root rot symptoms (Table 6). Although both taproot and lateral root tissues were used for DNA extractions, the detection results (Ct values) were not significantly different.

The $F$. virguliforme-specific qPCR assay presented here allows for the rapid and accurate quantification of $F$. virguliforme, which will facilitate epidemiological studies and diagnosis of this pathogen in plant, soil, and environmental samples. The assay may be used to screen for root rot resistance where visual estimation or culture-based methods are difficult or not practical. In addition, the assay may be used to potentially predict the preplant risk of SDS development if $F$. virguliforme inoculum thresholds can be established.

\section{ACKNOWLEDGMENTS}

We thank J. Haudenshield and G. Hartman of the United States Department of Agriculture-Agricultural Research Service at the University of Illinois at Urbana Champaign for generously providing the HHIC plasmid, and E. Gachango and W. Kirk for sharing Fusarium strains. This work was supported by grants from Project GREEEN (number GR10-113), the Michigan Soybean Promotion Committee, and the A.L. Rogers Endowed Research Scholarship.

\section{LITERATURE CITED}

1. Achenbach, L. A., Patrick, J. A., and Gray, L. E. 1996. Use of RAPD markers as a diagnostic tool for the identification of Fusarium solani isolates that cause soybean sudden death syndrome. Plant Dis. 80:12281232.

2. Akamatsu, H. O., Chilvers, M. I., Kaiser, W. J., and Peever, T. L. 2012. Karyotype polymorphism and chromosomal rearrangement in populations of the phytopathogenic fungus, Ascochyta rabiei. Fungal Biol. 116:11191133 .

3. Aoki, T., O’Donnell, K., Homma, Y., and Lattanzi, A. 2003. Sudden-death syndrome of soybean is caused by two morphologically and phylogenetically distinct species within the Fusarium solani species complex $F$. virguliforme in North America and F. tucumaniae in South America. Mycologia 95:660.

4. Aoki, T., O'Donnell, K., and Scandiani, M. M. 2005. Sudden death syndrome of soybean in South America is caused by four species of Fusarium: Fusarium brasiliense sp. nov., F. cuneirostrum sp. nov., F. tucumaniae, and F. virguliforme. Mycoscience 46:162-183.

5. Aoki, T., Scandiani, M. M., and O’Donnell, K. 2012. Phenotypic, molecular phylogenetic, and pathogenetic characterization of Fusarium crassistipitatum sp. nov., a novel soybean sudden death syndrome pathogen from Argentina and Brazil. Mycoscience 53:167-186.

6. Bilodeau, G. J., Koike, S. T., Uribe, P., and Martin, F. N. 2012. Development of an assay for rapid detection and quantification of Verticillium dahliae in soil. Phytopathology 102:331-343.

7. Brar, H. K., and Bhattacharyya, M. K. 2012. Expression of a single-chain variable-fragment antibody against a Fusarium virguliforme toxin peptide enhances tolerance to sudden death syndrome in transgenic soybean plants. Mol. Plant-Microbe Interact. 25:817-824.

8. Bustin, S. A., Benes, V., Garson, J. A., Hellemans, J., Huggett, J., Kubista, M., Mueller, R., Nolan, T., Pfaffl, M. W., Shipley, G. L., Vandesompele, J., and Wittwer, C. T. 2009. The MIQE guidelines: Minimum information for publication of quantitative real-time PCR experiments. Clin. Chem. 55:611-622.

9. Chilvers, M. I., du Toit, L. J., Akamatsu, H., and Peever, T. L. 2007. A real-time, quantitative PCR seed assay for Botrytis spp. that cause neck rot of onion. Plant Dis. 91:599-608.

10. Cho, J. H., Rupe, J. C., Cummings, M. S., and Gbur, E. E. 2001. Isolation and identification of Fusarium solani f. sp. glycines from soil on modified
Nash and Snyder's medium. Plant Dis. 85:256-260.

11. Edgar, R. C. 2004. MUSCLE: Multiple sequence alignment with high accuracy and high throughput. Nucleic Acids Res. 32:1792-1797.

12. Gachango, E., Hanson, L. E., Rojas, A., Hao, J. J., and Kirk, W. W. 2012. Fusarium spp. causing dry rot of seed potato tubers in Michigan and their sensitivity to fungicides. Plant Dis. 96:1767-1774.

13. Gao, X., Hartman, G., and Niblack, T. 2006. Early infection of soybean roots by Fusarium solani f. sp. glycines. (Abstr.) Phytopathology 96:S38.

14. Gao, X., Jackson, T. A., Lambert, K. N., Li, S., Hartman, G. L., and Niblack, T. L. 2004. Detection and quantification of Fusarium solani f. sp. glycines in soybean roots with real-time quantitative polymerase chain reaction. Plant Dis. 88:1372-1380.

15. Gramaje, D., Perez-Serrano, V., Montes-Borrego, M., Navas-Cortes, J. A., Jimenez-Diaz, R. M., and Landa, B. B. 2013. A comparison of real-time PCR protocols for the quantitative monitoring of asymptomatic olive infections by Verticillium dahliae pathotypes. Phytopathology 103:10581068.

16. Haudenshield, J. S., and Hartman, G. L. 2011. Exogenous controls increase negative call veracity in multiplexed, quantitative PCR assays for Phakopsora pachyrhizi. Plant Dis. 95:343-352.

17. Hayden, R. T., Hokanson, K. A., Pounds, S. B., Bankowski, M. J., Belzer, S. W., Carr, J., Diorio, D., Forman, M. S., Joshi, Y., Hillyard, D., Hodinka, R. L., Nikiforova, M. N., Romain, C. A., Stevenson, J., Valsamakis, A., Balfour, H. H., and Grp, U. E. W. 2008. Multicenter comparison of different real-time PCR assays for quantitative detection of Epstein-Barr virus. J. Clin. Microbiol. 46:157-163.

18. Herrera, M. L., Vallor, A. C., Gelfond, J. A., Patterson, T. F., and Wickes, B. L. 2009. Strain-dependent variation in $18 \mathrm{~S}$ ribosomal DNA Copy numbers in Aspergillus fumigatus. J. Clin. Microbiol. 47:1325-1332.

19. Jiang, J. L., Alderisio, K. A., Singh, A., and Xiao, L. H. 2005. Development of procedures for direct extraction of Cryptosporidium DNA from water concentrates and for relief of PCR inhibitors. Appl. Environ. Microbiol. 71:1135-1141.

20. Katoh, K., and Standley, D. M. 2013. MAFFT multiple sequence alignment software version 7: Improvements in performance and usability. Mol. Biol. Evol. 30:772-780.

21. Kolander, T. M., Bienapfl, J. C., Kurle, J. E., and Malvick, D. K. 2012. Symptomatic and asymptomatic host range of Fusarium virguliforme, the causal agent of soybean sudden death syndrome. Plant Dis. 96:11481153.

22. Larkin, M. A., Blackshields, G., Brown, N. P., Chenna, R., McGettigan, P. A., McWilliam, H., Valentin, F., Wallace, I. M., Wilm, A., Lopez, R., Thompson, J. D., Gibson, T. J., and Higgins, D. G. 2007. Clustal W and Clustal X version 2.0. Bioinformatics 23:2947-2948.

23. Li, S., and Hartman, G. L. 2003. Molecular detection of Fusarium solani f. sp. glycines in soybean roots and soil. Plant Pathol. 52:74-83.

24. Li, S., Hartman, G. L., Domier, L. L., and Boykin, D. 2008. Quantification of Fusarium solani f. sp. glycines isolates in soybean roots by colony-forming unit assays and real-time quantitative PCR. Theor. Appl. Genet. 117:343-352.

25. Long, E. O., and Dawid, I. B. 1980. Repeated genes in eukaryotes. Annu. Rev. Biochem. 49:727-764.

26. Luo, Y., Myers, O., Lightfoot, D., and Schmidt, M. 1999. Root colonization of soybean cultivars in the field by Fusarium solani f. sp. glycines. Plant Dis. 83:1155-1159.

27. Malvick, D., and Impullitti, A. 2007. Detection and quantification of Phialophora gregata in soybean and soil samples with a quantitative, realtime PCR assay. Plant Dis. 91:736-742.

28. Malvick, D. K., and Grunden, E. 2005. Isolation of fungal DNA from plant tissues and removal of DNA amplification inhibitors. Mol. Ecol. Notes 5:958-960.

29. Mbofung, G. C. Y., Fessehaie, A., Bhattacharyya, M. K., and Leandro, L. F. S. 2011. A new TaqMan real-time polymerase chain reaction assay for quantification of Fusarium virguliforme in soil. Plant Dis. 95:1420-1426.

30. Navi, S. S., and Yang, X. 2008. Foliar symptom expression in association with early infection and xylem colonization by Fusarium virguliforme (formerly $F$. solani f. sp. glycines), the causal agent of soybean sudden death syndrome. Plant Health Progress. doi:10.1094/PHP-2008-0222-01-RS

31. Notredame, C., Higgins, D. G., and Heringa, J. 2000. T-Coffee: A novel method for fast and accurate multiple sequence alignment. J. Mol. Biol. 302:205-217.

32. O'Donnell, K., and Gray, L. E. 1995. Phylogenetic relationships of the soybean sudden death syndrome pathogen Fusarium solani f. sp. phaseoli inferred from rDNA sequence data and PCR primers for its identification. Mol. Plant-Microbe Interact. 8:709-716.

33. O'Donnell, K., Sink, S., Scandiani, M. M., Luque, A., Colletto, A., Biasoli, M., Lenzi, L., Salas, G., Gonzalez, V., Ploper, L. D., Formento, N., Pioli, R. N., Aoki, T., Yang, X. B., and Sarver, B. A. 2010. Soybean sudden death syndrome species diversity within North and South America revealed by multilocus genotyping. Phytopathology 100:58-71. 
34. O'Donnell, K., Sutton, D. A., Fothergill, A., McCarthy, D., Rinaldi, M. G., Brandt, M. E., Zhang, N., and Geiser, D. M. 2008. Molecular phylogenetic diversity, multilocus haplotype nomenclature, and in vitro antifungal resistance within the Fusarium solani species complex. J. Clin. Microbiol. 46:2477-2490.

35. Patrinos, G. P., and Ansorge, W. 2010. Molecular Diagnostics, Vol. XVI. Elsevier Academic Press, Amsterdam, Boston.

36. Rice, P., Longden, I., and Bleasby, A. 2000. EMBOSS: The European molecular biology open software suite. Trends Genet. 16:276-277.

37. Roy, K. W., Lawrence, G. W., Hodges, H. H., Mclean, K. S., and Killebrew, J. F. 1989. Sudden death syndrome of soybean: Fusarium solani as incitant and relation of Heterodera glycines to disease severity. Phytopathology 79:191-197.

38. Roy, K. W., Rupe, J. C., Hershman, D. E., and Abney, T. S. 1997. Sudden death syndrome of soybean. Plant Dis. 81:1100-1111.

39. Rupe, J. C. 1989. Frequency and pathogenicity of Fusarium solani re- covered from soybeans with sudden death syndrome. Plant Dis. 73:581-584. 40. Schaad, N. W., and Frederick, R. D. 2002. Real-time PCR and its application for rapid plant disease diagnostics. Can. J. Plant Pathol. 24:250-258.

41. Srivastava, S. K., Huang, X., Brar, H. K., Fakhoury, A. M., Bluhm, B. H., and Bhattacharyya, M. K. 2014. The genome sequence of the fungal pathogen Fusarium virguliforme that causes sudden death syndrome in soybean. PLoS One 9:e81832.

42. Wickham, H. 2009. ggplot2: Elegant graphics for data analysis, Use $R$.

43. Wrather, J., and Koenning, S. 2010. Suppression of soybean yield potential in the continental United States by plant diseases from 2006 to 2009. Plant Health Progress. doi:10.1094/PHP-2010-1122-01-RS

44. Wrather, J., and Koenning, S. 2011. Soybean disease loss estimates for the United States, 1996-2010. http://aes.missouri.edu/delta/research/ soyloss.stm

45. Zuker, M. 2003. Mfold web server for nucleic acid folding and hybridization prediction. Nucleic Acids Res. 31:3406-3415. 